\author{
최창원 · 백경훈 ${ }^{1 *} \cdot$ 최창본 ${ }^{1} \cdot$ 오영균 · 홍성구 \\ 농촌진흥청 국립축산과학원, ${ }^{1}$ 영남대학교
}

\title{
Development of Polyclonal Antibodies to Abdominal and Subcutaneous Adipocyte for Producing Fat-reduced High Quality Pork
}

\author{
Chang Weon Choi, Kyung Hoon Baek ${ }^{1 *}$, Chang Bon $\mathrm{Choi}^{1}$, Young Kyoon Oh, and Seong Koo Hong \\ Nutrition and Physiology Team, National Institute of Animal Science, RDA, Suwon 441-706, Korea \\ ${ }^{I}$ School of Biotechnology, Yeungnam University, Gyeongsan 712-749, Korea
}

\begin{abstract}
The aim of the present study was to develop polyclonal antibodies to regional inedible adipocytes of pigs and investigate the effect of these antibodies on adipocytes in vitro. As antigens, abdominal and subcutaneous adipocyte PMPs from pigs were injected into sheep 3 times per 3 wk intervals for passive immunization, and non-immunized serum, antisera against abodominal (AAb) or subcutaneous adipocyte PMPs $(\mathrm{SAb})$ were collected before and after the injections. Titers of the antisera obtained from sheep and their cross-reactivities with the heart, kidney, liver, lung, muscle, and spleen of pig were determined by ELISA. Isolation and culture of abdominal and subcutaneous adipocytes from pigs were performed to analyze LDH concentration. At a 1:1,000 dilution, little antibody reactivity was observed for non-immunized serum whereas both $\mathrm{AAb}$ and SAb had relatively strong reactivity up to a dilution of 1:16,000. These findings may indicate that strong antibodies against adipocyte PMPs can be developed using an immunological approach. Extremely low reactivity of AAb and SAb was detected with the PMPs of the organs. Both antisera most strongly reacted with each adipocyte PMPs and showed statistically $(p<0.05)$ higher cross-reactivities compared with the non-immunized serum. In conclusion, these results may indicate that the present polyclonal antibodies against regional inedible adipocyte PMPs are well developed and are safe against cross-reactivities with the organs of pigs. Further studies on the in vivo nutritional safety and fat reduction of these antibodies in pigs will be required fat-reduced high quality pork production.
\end{abstract}

Key words : high quality pork, antibody, subcutaneous adipocyte, cross-reactivity

\section{서 론}

Flint 등(1986)이 흰쥐 지방세포에 대한 항체를 이용하 여 면역학적인 체지방 감소 기법을 발표한 이래 현재까지 다양한 축종들, 돼지(Kestin et al., 1993; Baek et al., 2007), 흰쥐(Flint et al., 1986), 한우(Choi et al., 1997), 면양(Nassar and Hu, 1991), 닭(Dong et al., 1991; Butterwith et al., 1992) 등을 대상으로 많은 연구들이 진행되어왔다. 이 방 법은 지방세포 원형질막 단백질에 대한 항체를 이용하여 육생산 동물의 지방세포를 직접 파괴시키는 방법으로, 기 존의 유전자재조합 방법을 이용한 성장호르몬, $\beta$-adrenergic

*Corresponding author : Kyung Hoon Baek, School of Biotechnology, Yeungnam University, Gyeongsan, 712-749, Korea. Tel: 82-53-810-3023, Fax: 82-53-810-4769, E-mail: nuno@ ynu.ac.kr agents, 또는 somatostatin에 대한 항체의 이용 등과 같이 호르몬에 바탕을 둔 체지방 감소 기법이 가지고 있는 문 제점들(특히, 외부물질의 체내 잔류 가능성 등으로 인한 인체 유해 논쟁; Moloney, 1995)을 극복한 보다 소비자 선 호적인 친근한 연구기법으로 잘 알려져 있다(Baek, 2003). 실제 Kestin 등(1993)은 돼지 지방세포 원형질막에 대한 다클론 항체를 돼지에게 피하주사 하였을 때, 등지방 두 께가 국소적으로 감소되는 결과 $(p<0.01)$ 를 확인하였으며, 복강주사 시, 체지방이 $25 \%$ 감소되는 결과를 보고하였다. 또한, 면양 지방에 대한 항체를 이용한 연구에서 항체는 대조구 대비 면양의 신장지방 $(14.0 \rightarrow 11.5 \%)$ 및 장간막지 방 $(25.0 \rightarrow 5.0 \%)$ 을 크게 감소시켰으며 지방세포의 파괴로 야기되는 체 단백질의 보상적 증가 효과 $(16 \%$; Moloney and Allen, 1989a) 또한 보고되어, 항체의 처리는 체지방 감소뿐만 아니라 사료 이용성 또한 향상된다고 알려져 있 
다(Futter and Flint, 1987; Moloney and Allen, 1989b; Panton et al., 1990).

하지만 현재까지의 연구들은 항체의 생산 및 항체가 가 지는 지방세포 독성 및 감소 효과 등에 초점이 맞춰져 왔 었기 때문에 본 기술의 상용화를 위해서는 반드시 해결해 야 할 문제들이 존재한다. 특히 우리나라의 돼지고기 등 급 및 소비자 선호 특성상 근내지방은 유지하면서 불가식 지방인 복강 및 피하지방 만을 선택적으로 감소시키는 이 른바 지방부위별 선택적 감소기술의 개발이 요구되며 또 한 개발된 항체의 심장, 신장, 간장 등 생체 내 주요 장기 들과의 교차반응 등의 세밀한 검증이 필요하다. 지금까지 의 돼지 지방 감소 항체 연구에서 항원으로 사용된 지방 또는 지방세포 원형질막 단백질(plasma membrane proteins, $\mathrm{PMP})$ 은 전체 지방조직 또는 불특정 지방부위에서 원형질 막 단백질을 분리하여 사용되었기 때문에 원치 않는 부작 용들이 보고된 바 있다. 흰쥐의 지방세포에 대한 항혈청 이 간세포의 원형질막 단백질과 교차반응을 나타내었고 (Flint et al., 1986), Panton 등(1990)은 흰쥐의 지방세포에 대한 항혈청이 간세포와 $16 \%$ 수준의 교차반응이 일어난 다고 보고하였다. 또한, $\mathrm{Hu}$ 등(1992)은 흰쥐 지방세포 원 형질막 단백질에 대한 항체를 흰쥐에 수동면역 주사한 결 과, 처리구의 비장 크기가 증가하였으며 조직의 색깔이 대 조구에 비해 짙어짐을 보고하였는데, 이 또한 다클론 항 체의 특성으로 인한 교차반응일 것이라고 추측하였다. 흰 쥐뿐만 아니라 이와 유사한 보고들은 토끼(Dulor et al., 1990), 면양(Nassar and $\mathrm{Hu}, 1991)$ 등에서도 보고되었으며, 가금류인 닭에서도 보고된 바 있다(Dong et al., 1990). 따 라서, 본 연구는 불가식 체지방이 감소된 저지방 고품질 돼지고기 생산을 위해 현재까지 나타난 다클론 항체들의 단점을 극복하는 부위별 즉, 복강(polyclonal antibody to abdominal adipocyte PMP, $\mathrm{AAb}$ ) 및 피하 지방 다클론 항 체(polyclonal antibody to subcutaneous adipocytes PMP, $\mathrm{SAb}$ )를 개발하고자 실시되었다.

\section{재료 및 방법}

\section{지방 및 장기 세포 원형질막 단백질 분리}

본 연구에서 지방 및 장기세포 원형질막 단백질의 분리 를 위해 필요한 돼지 지방 및 주요 장기 조직들은 삼원교 잡종 $($ Landrace $\times$ Large white $) \times$ Duroc) 암퇘지 $($ 생후 180 일 령, 약 $110 \mathrm{~kg}$ ) 1 두를 공시하여 도축시 적출하여 확보하였다.

\section{지방세포 원형질막 단백질 분리}

본 연구에서 항원으로 사용될 복강 및 피하 지방세포 PMP는 Kestin 등(1993)의 방법에 따라 분리하였다. 국립 축산과학원 도축장에서 도축 즉시 돼지 복강 및 피하지방 조직을 채취하여 $0.9 \%$ 생리식염수 $\left(70 \pm 5^{\circ} \mathrm{C}\right)$ 에 넣어 지방조
직이 굳지 않게 유지하면서 실험실로 이동했다. 지방조직 에서 혈관 및 결체조직 등을 최대한 제거하면서 가위로 잘게 세절한 후, Digestion media((Dulbecco's Modified Eagle Medium(DMEM, Hyclone SH30243.01), 0.1\% collagenase(SIGMA C-6885), 30\% bovine serum albumin(BSA, SIGMA A-2153))와 지방의 비율을 2:1로 하여 항온수조에 서 collagenase digestion $\left(42^{\circ} \mathrm{C}, 90 \mathrm{~min}\right)$ 을 실시하였다. 분 해 후 collagenase로 인해 유리된 지방세포들만을 따로 취 하기 위해 $250 \mu \mathrm{m}$ 나일론 망으로 걸러주었으며, $37^{\circ} \mathrm{C}$ 에 서 5 분 간 정치하여 미성숙한 지방세포들로 구성된 하층 을 제거함으로써 지방입자를 함유하고 있는 성숙한 지방 세포들을 선택적으로 추출하였다. 그 후 보다 순수한 세 포를 얻기 위해 collagenase를 제거한 소화용액(세척용액) 로 3회 세척 하였다.

분리된 지방 세포층과 $\mathrm{MEM(membrane} \mathrm{extraction} \mathrm{medium;}$ $0.25 \mathrm{M}$ sucrose, $0.01 \mathrm{M} \mathrm{Na}_{2} \mathrm{HPO}_{4}, 2 \mathrm{mM}$ EGTA, $200 \mathrm{~mL}$ 증 류수, $\mathrm{pH}$ 7.4)을 1:2의 비율로 혼합한 후 $50 \mathrm{~mL}$ tube에 30 $\mathrm{mL}$ 씩 넣고, $0.2 \mathrm{M}$ PMSF(phenyl methyl sulphonyl flouride) 를 각 시험관당 $60 \mu \mathrm{L}$ 씩 첨가한 후 손으로 격렬히 흔들어 지방세포를 파괴시켰다. 원심분리기(UNION 32R PLUS, HANIL science, Korea)로 $3,000 \mathrm{rpm}$ 에서 5 분 간 원심분 리 한 뒤 얼음 통에 약 10 분간 정치시켜 지방세포 파괴 로 생성된 중성지방층을 조심스럽게 제거한 뒤, 하층액을 $4^{\circ} \mathrm{C}$, 초고속 원심분리 $(110,000 \mathrm{~g}, 1 \mathrm{~h}$; HIMAC CP 70MX, HITACHI, Japan)하였다. 원심분리 후 생성된 펠렛들 중 원형질막 단백질만을 따로 추출하기 위해 펠렛을 $32 \%$ sucrose media와 함께 유리교반기에서 충분히 현탁하고, 현탁액을 swing rotor로 옮겨 넣고 초고속 원심분리 $\left(4^{\circ} \mathrm{C}\right.$, $148,000 \mathrm{~g}, 1 \mathrm{~h})$ 하여 분리되는 단백질 밴드만을 따로 채취 하였다. 순수한 원형질막 단백질을 정제해 내기 위해 다 시 단백질 밴드를 MEM으로 충분히 현탁한 뒤 초고속 원 심분리하여 최종 pellet 즉 adipocyte PMP를 분리하였다. 분 리된 adipocyte PMP의 량에 따라 적당량의 MEM을 첨가 한 뒤 단백질정량용액(500-0116, Bio-RAD, USA)를 이용 해 단백질 농도를 측정하고 본 실험의 항원으로 사용될 때까지 $-20^{\circ} \mathrm{C}$ 에서 보관하였다.

\section{장기조직 원형질막 단백질 분리}

돼지의 심장, 신장, 간장, 폐, 근육 및 비장 PMP 분리는 Choi 등(2008)의 방법을 응용하여 실시하였다. 도축장에서 장기조직을 채취 즉시 $50 \mathrm{~mL}$ tube에 $5 \mathrm{~g}$ 씩 넣고 MEM $25 \mathrm{~mL}$ 와 $0.2 \mathrm{M}$ PMSF $60 \mu \mathrm{L}$ 를 첨가한 뒤 교반기(WiseMix HG$15 \mathrm{D}$, DAEHAN Science, Korea)를 이용하여 분쇄 하였다. 분쇄한 현탁액을 새로운 $50 \mathrm{~mL}$ tube에 옮겨 넣고 $4^{\circ} \mathrm{C}$, $3,000 \mathrm{rpm}, 30$ 분간 원심분리 한 뒤, 상층액만 취하여 다시 $4^{\circ} \mathrm{C}, 110,000 \mathrm{~g}$ 에서 1 시간 동안 초고속 원심분리 하였다. 원심분리 후 펠렛을 $32 \%$ sucrose media와 함께 glass 
grinder에 넣고 충분히 현탁한 후 sucrose gradient를 위해 다시 초고속 원심분리 $\left(4^{\circ} \mathrm{C}, 148,000 \mathrm{~g}, 1 \mathrm{~h}\right)$ 를 실시하였다. 원심분리관에 형성된 단백질밴드를 확인한 뒤, 조심스럽게 단백질층만을 취하고 $\mathrm{MEM}$ 을 첨가한 뒤 다시 초고속 원 심분리 $\left(148,000 \mathrm{~g}, 4^{\circ} \mathrm{C}, 1 \mathrm{~h}\right)$ 하여 단백질 pellet을 분리하 였다. 분리된 pellet의 량에 따라 적당량의 $\mathrm{MEM}$ 을 첨가 한 뒤 adipocyte PMP와 동일하게 단백질정량 키트를 이 용해 단백질 농도를 측정하였다. 본 연구에서 분리된 돼 지 주요장기 PMP는 돼지 부위별 adipocyte PMP에 대한 항혈청의 교차반응성 측정 등에 사용되었으며, 사용 시까 지 $-20^{\circ} \mathrm{C}$ 에서 보관하였다.

\section{돼지 복강 및 피하 지방 특이 항체의 생산}

돼지 $\mathrm{AAb}$ 및 $\mathrm{SAb}$ 생산을 위한 수동면역주사는 Baek 등(2005)의 방법에 따라 실시하였다. Corriedale 면양 수컷 (약 $62 \mathrm{~kg}$ )의 피하 3 부위(목 뒷부분과 양쪽 서혜부)에 adipocytes PMP을 면역주사 하였으며, 최초 면역주사 이 후 2차례 더 boosting 면역주사를 3 주 간격으로 실시하였 다. 1차 접종에는 adipocyte PMP $1 \mathrm{~mL}(250 \mu \mathrm{g} / \mathrm{mL})$, Freund's incomplete adjuvant(Sigma F5881, USA) $1,750 \mu \mathrm{L}$ 그리고 Freund's complete adjuvant(Sigma F5506, USA) $250 \mu \mathrm{L}$ 를 3-way stopcock(성원메디칼, 한국)을 사용해 충분히 혼합 한 뒤 $1 \mathrm{~mL}$ 씩 나누어 전술한 피하 3부위에 주사하였으며, 2차와 3차 접종에는 adipocytes PMP의 농도를 반으로 줄 인 항원 $1 \mathrm{~mL}(125 \mu \mathrm{g} / \mathrm{mL})$ 에 Freund's incomplete adjuvant $2 \mathrm{~mL}$ 첨가하여 전술한 방법과 동일하게 면역 접종하였다. 1 차 면역접종 전 면양의 경정맥을 통해 혈액을 채취한 뒤 상온에서 1 시간 정치시켜 혈액을 응고시키고, $2,800 \mathrm{rpm}$ 에서 30 분 간 원심분리 하여 비면역혈청을 분리하였다. 또 한, 마지막 면역접종이 끝난 후 12 일째에 채혈한 후 비면 역혈청 분리 시와 동일한 방법으로 항혈청(항체)을 분리 하였다. 위의 방법으로 생산한 돼지 복강 및 피하지방 PMP 에 대한 항혈청들은 각각 돼지 복강지방 항체(AAb) 및 피 하지방 항체 $(\mathrm{SAb})$ 로 명명하였다. 생산된 비면역혈청 및 항 혈청들은 사용 전까지 $-80^{\circ} \mathrm{C}$ 에서 냉동보관 하였다.

항체의 역가, 타장기 cross-reactivity 및 세포독성 검사

\section{지방 특이 항체의 역가 측정}

본 연구에서 생산한 돼지 부위 별 지방 항체의 역가는 Kestin 등(1993)과 Choi 등(2008)의 ELISA법에 따라 측정 하였다. ELISA 항체 역가 측정법은 개발된 항체를 일차 항체로 희석 후 농도 별로 반응시키는 것으로, 일반적으 로 혈청 내 항체의 수준을 검사하기 위해 많이 사용된 방 법이다(Flint et al., 1986; Nassar and Hu, 1991; Choi et al., 2008). 역가 측정 하루 전 돼지 복강 및 피하지방 PMP 를 $1 \mu \mathrm{g} / \mathrm{mL}$ 의 농도로 TBS(Tris-buffered Saline, $\mathrm{pH} 7.2$ :
$50 \mathrm{mM}$ Tris, $154 \mathrm{mM} \mathrm{NaCl}$ )에 희석한 뒤 96 well plate (Costar 3590, USA)에 $100 \mu \mathrm{L}$ 씩 분주하여 바닥에 완전히 흡착시키고 24 시간 정치시켰다. Plate의 상층액을 제거한 뒤 TBS-Tween(0.1\% Tween 20) $200 \mu \mathrm{L}$ 를 넣어 3회 세척 한 후 비면역혈청 및 항혈청을 1 차 항체로써 $100 \mu \mathrm{L}$ 씩 주 입하여 항원과 결합시켰다. 상온에서 2 시간 반응시킨 후 TBS-Tween으로 3회 세척하고, 그 후 2차 항체로 anti-sheep $\mathrm{IgG}$ (Sigma A5187, USA)를 1:10,000배 희석하여 각 well 에 $100 \mu \mathrm{L}$ 씩 주입하고 상온에서 다시 2시간 동안 반응시 켰다. 다시 TBS-Tween으로 3회 세척 한 후 alkaline phosphatase substrate에 4-NP(Sigma 1040, USA)를 섞은 반응 용액를 $250 \mu \mathrm{L}$ 씩 첨가하여 암실에서 반응이 일어날 때까 지(약 15 분 소요) 발색시켰다. $0.5 \mathrm{M} \mathrm{NaOH}$ 을 각 well 당 $50 \mu \mathrm{L}$ 씩 첨가하여 발색 반응을 정지 시킨 후 흡광도계 (Benchmark plus model 680, Bio-Rad, USA)를 이용하여 $405 \mathrm{~nm}$ 에서 흡광도를 측정하였다.

\section{지방 특이 항체의 타장기 교차반응}

본 연구에서 생산한 $\mathrm{AAb}$ 및 $\mathrm{SAb}$ 가 돼지의 심장, 신장, 간장, 폐, 근육 및 비장세포 $\mathrm{PMP}$ 와의 교차반응성 즉, 타 장기 교차반응는 Paik 등(2000)의 방법에 따라 ELISA법 으로 실시하였다. 실험 전날 지방세포를 포함한 돼지 장 기 세포 PMP를 $1 \mu \mathrm{g} / \mathrm{mL}$ 의 농도로 $\mathrm{TBS}$ 와 희석한 뒤 각 well 당 $100 \mu \mathrm{L}$ 씩 96 well plate에 주입하여 항원이 plate 바닥 에 충분히 coating 되도록 해 주었다. 전체적인 실험의 방 법은 지방 특이 항체의 역가 측정법과 동일하게 수행되었 으며, 암실에서 약 30 분 간 발색반응 시킨 후 $405 \mathrm{~nm}$ 에서 흡광도를 측정하였다.

\section{돼지 지방세포 배양 및 항체 세포독성}

돼지 부위 별 지방세포 원형질막에 대한 특이항체들(AAb 및 $\mathrm{SAb}$ )의 in vitro 세포배양 및 세포독성 효과 검증을 위해 Baek(2003)의 방법에 따라 세포배양 후 lactate dehydrogenase $(\mathrm{LDH})$ assay를 실시하였다.

\section{통계분석}

돼지 부위 별 지방 특이 항체의 역가 연구의 통계분석 은 SAS(2002) 통계 프로그램에 포함된 일반선형모형으로 상호작용 효과가 있는 이원 분산분석을 실시하였고, 통계 모형을 다음과 같다.

$$
\mathrm{Y}_{\mathrm{ijk}}=\mu+\alpha_{\mathrm{i}}+\beta_{\mathrm{j}}+(\alpha \beta)_{\mathrm{ij}}+\varepsilon_{\mathrm{ijk}}
$$

여기에서 $\mu$ 는 전체평균, $\alpha_{\mathrm{i}}$ 는 $\mathrm{i}$ 번째 처리구 간의 효과, $\beta_{\mathrm{j}}$ 는 $\mathrm{j}$ 번째 희석배율에 따른 효과, $(\alpha \beta)_{\mathrm{ij}}$ 는 $\mathrm{i}$ 처리구와 $\mathrm{j}$ 희 석배율간의 상호작용, $\mathrm{Y}_{\mathrm{ijk}}$ 는 관측된 흡광도를 나타내며, $\varepsilon_{\mathrm{ijk}}$ 는 각각의 실험에서의 오차를 나타낸다. 역가, 교차반응 성 및 세포독성 등 각각의 자료에 대한 유의성 검증은 
Duncan (1955)의 다중검정법으로 $95 \%$ 신뢰수준에서 검증 하였다.

\section{결과 및 고찰}

\section{항체의 역가 측정 및 타장기 cross-reactivity 연구}

\section{돼지 부위별 지방 특이 항체의 역가}

Fig. 1은 본 연구에서 생산한 돼지 복강지방세포 특이 항체의 역가를 측정하기 위해 항원 $1 \mu \mathrm{g} / \mathrm{mL}$ 에 대해 항혈 청을 $1: 1,000$ 배부터 $1: 128,000$ 배까지 순차적으로 희석하여 처리한 ELISA 결과로, $1: 1,000$ 배의 희석배율에서 감지된 돼지 복강지방세포에 대한 항혈청의 역가를 백분율로 계 산한 결과를 나타낸 것이다.

희석배율과 처리에 따른 이원분산분석을 실시해본 결과, 항원-항체반응으로 나타난 흡광도는 희석배율에 따라 유 의적인 차이를 나타내었으며 $(p<0.001)$, 처리에 따른 유의

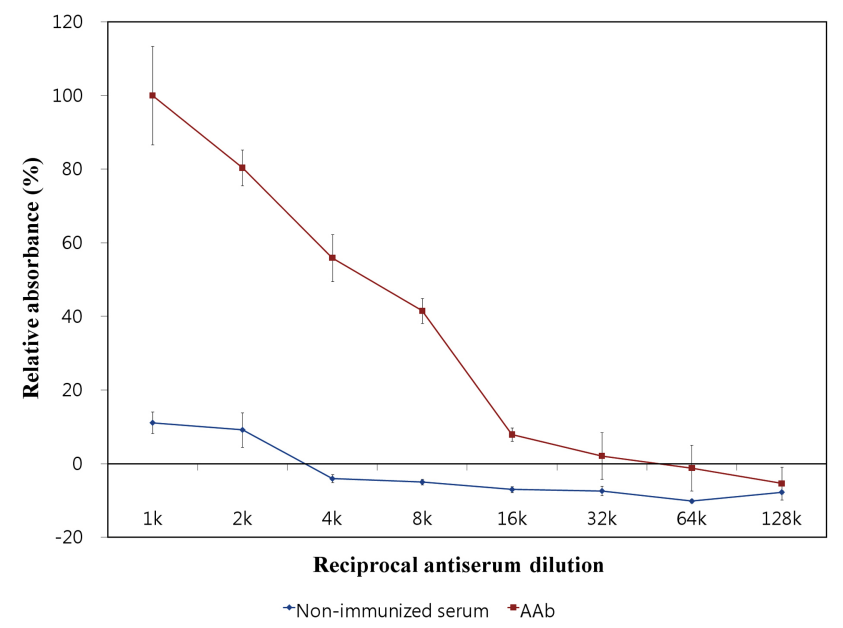

Fig. 1. Reactivity of non-immunized serum and antiserum against abdominal adipocyte plasma membrane proteins of pigs (AAb) as detected by ELISA. Mean $\pm \mathrm{SE}(\mathrm{n}=6)$.
적인 차이도 나타내었다 $(p<0.001)$. 또한 희석배율과 처리 간의 상호작용도 유의적인 것으로 나타났다 $(p<0.001)$. Fig. 1 에서 보는 바와 같이 비면역혈청 $(-0.054 \pm 0.006)$ 과 비교 시 $\mathrm{AAb}(0.061 \pm 0.014)$ 는 돼지 복강지방세포에 대해 $1: 16,000$ 희석배율에서 유의적으로 $(p<0.05)$ 높은 항원-항체 반응을 나타내었다. $\mathrm{SAb}$ 의 역가 또한 $\mathrm{AAb}$ 와 동일하게 희석배율 $(p<0.001)$, 처리 $(p<0.001)$ 및 상호작용 $(p<0.001)$ 모두 유의

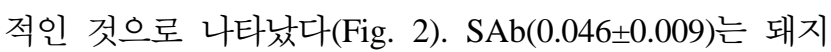
피하지방세포에 대해 $1: 16,000$ 배 희석배율까지 유의적으 로 $(p<0.05)$ 높은 역가를 보였으며(비면역혈청 : 0.022士 0.006), 희석배율이 높아짐에 따라 역가가 순차적으로 감 소하는 경향을 나타내면서 1:32,000 배 희석배율에서는 항

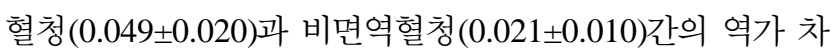
이는 나타나지 않았다. Fig. 1 및 2의 역가 패턴에서 알 수 있듯이 동일한 면양으로부터 항원 접종 전 채취된 비면역 혈청에서는 ELISA반응이 나타나지 않는 반면 지방세포 $\mathrm{PMP}$ 접종 후 채취된 $\mathrm{AAb}$ 및 $\mathrm{SAb}$ 에서는 높은 항원-항체

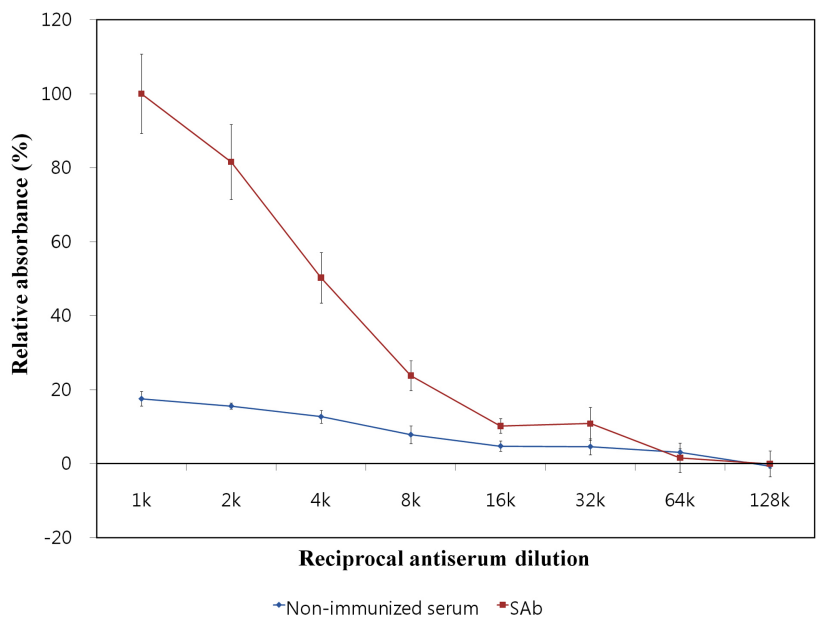

Fig. 2. Reactivity of non-immunized serum and antiserum against subcutaneous adipocyte plasma membrane proteins of pigs (SAb) as detected by ELISA. Mean \pm SE $(n=6)$.

Table 1. Optical density of antiserum against abdominal adipocyte plasma membrane proteins of pigs (AAb) with abdominal and subcutaneous adipocytes, heart, kidney, liver, lung, muscle and spleen of pigs ${ }^{1)}$

\begin{tabular}{llllc}
\hline \multicolumn{1}{c}{ Items } & $3 \mathrm{k}$ & $9 \mathrm{k}$ & $27 \mathrm{k}$ & $81 \mathrm{k}$ \\
\hline Abdominal adipocyte & $2.103^{\mathrm{a}}$ & $1.738^{\mathrm{a}}$ & $1.466^{\mathrm{a}}$ & $1.102^{\mathrm{a}}$ \\
Subcutaneous adipocyte & $1.848^{\mathrm{b}}$ & $1.439^{\mathrm{b}}$ & $1.244^{\mathrm{b}}$ & $0.847^{\mathrm{b}}$ \\
Heart & $0.947^{\mathrm{c}}$ & $0.780^{\mathrm{c}}$ & $0.637^{\mathrm{d}}$ & $0.599^{\mathrm{c}}$ \\
Kidney & $0.892^{\mathrm{d}}$ & $0.703^{\mathrm{cd}}$ & $0.610^{\mathrm{d}}$ & $0.560^{\mathrm{c}}$ \\
Liver & $0.902^{\mathrm{cd}}$ & $0.788^{\mathrm{c}}$ & $0.608^{\mathrm{d}}$ & $0.562^{\mathrm{c}}$ \\
Lung & $0.870^{\mathrm{d}}$ & $0.787^{\mathrm{c}}$ & $0.707^{\mathrm{c}}$ & $0.579^{\mathrm{c}}$ \\
Muscle & $0.871^{\mathrm{d}}$ & $0.656^{\mathrm{d}}$ & $0.597^{\mathrm{d}}$ & $0.583^{\mathrm{c}}$ \\
Spleen & $0.912^{\mathrm{cd}}$ & $0.754^{\mathrm{cd}}$ & $0.594^{\mathrm{d}}$ & $0.576^{\mathrm{c}}$ \\
SEM $^{2)}$ & 0.022 & 0.043 & 0.019 & 0.037 \\
\hline
\end{tabular}

$\overline{\mathrm{a}, \mathrm{b}, \mathrm{c}, \mathrm{d}}$ Means with different superscripts within the same row are significantly different $(p<0.05)$.

${ }^{1)}$ Optical density was measured at $405 \mathrm{~nm}$ using a microplate reader. Interaction between treatment and dilution rate were significant $(p<0.001)$.

${ }^{2)}$ Standard error of mean. 


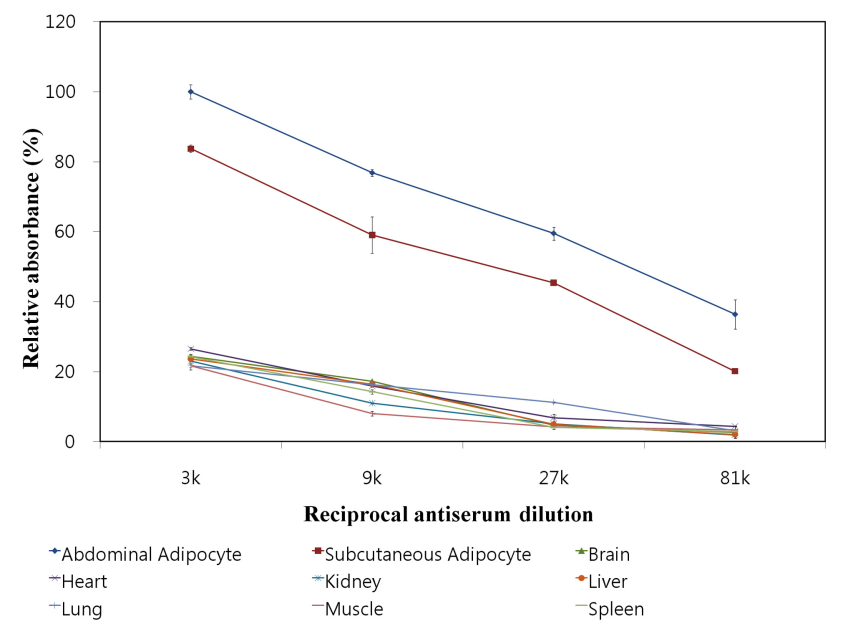

Fig. 3. Cross-reactivity of antiserum against abdominal adipocyte plasma membrane proteins of pigs (AAb) with abdominal and subcutaneous adipocytes, heart, kidney, liver, lung, muscle and spleen of pigs. Mean \pm SE ( $n=6)$.

반응을 나타내었다. 이것은 Kestin 등(1993)이 보고한 돼 지의 지방세포 원형질막 단백질을 면양에 면역 접종하여 생산한 항혈청이 $1: 27,000$ 배의 희석배율에서도 지방세포 에 대해 역가를 보이는 것과도 유사한 결과이다. Flint 등 (1986) 역시 흰쥐 지방 항체 생산 시 유사한 역가 패턴을 보고하였고, 국내에서는 돼지 전체 지방세포에 대해 생산 한 항체가 $1: 32,000$ 배의 희석배율에서도 감지할 수 있었 다고 하였다(Choi and Lee, 1996). 최근 본 연구팀이 보고 한 한우 부위 별 지방 항체의 역가와의 비교(Choi et al., 2008)에서도 비록 그 희석배율에 따라 감응의 차이가 다 소 존재할 뿐 지방세포에 대한 특이적으로 반응하는 전체 적인 항체의 역가 패턴은 유사하게 나타났다. 따라서 기 존의 보고된 전체지방에 대한 항체의 역가와 비교 시 본 연구에서 생산된 $\mathrm{AAb}$ 및 $\mathrm{SAb}$ 모두 돼지 지방세포에 대 해 강한 결합력을 가진 특이적 항체인 것으로 판단된다.

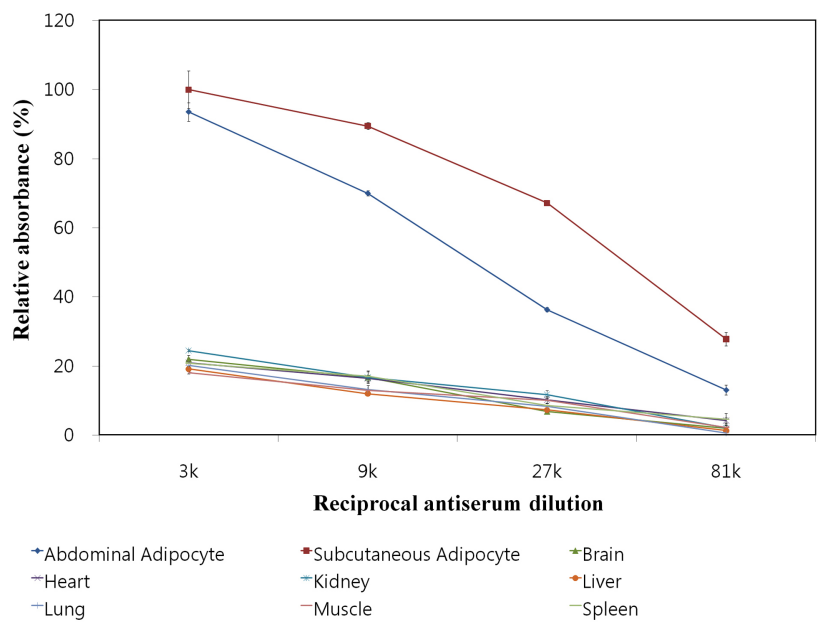

Fig. 4. Cross-reactivity of antiserum against subcutaneous adipocyte plasma membrane proteins of pigs $(\mathrm{SAb})$ with abdominal and subcutaneous adipocytes, heart, kidney, liver, lung, muscle and spleen of pigs. Mean $\pm \mathrm{SE}$ $(n=6)$.

\section{돼지 부위별 지방 특이 항체의 타장기 안전성 연구}

Fig. 3 및 4는 돼지 AAb 및 SAb의 생체 장기세포 PMP 에 대한 교차반응도를 나타낸 것이고, Table 1 및 2 는 교 차반응도 측정시험의 실측 값(optical density, OD)을 제시 한 것이다.

역가 측정시와 동일하게 이원분산분석을 실시해본 결과, 두 실험결과는 공히 항원-항체반응으로 나타난 주요장기 별 흡광도가 희석배율 $(p<0.001)$, 처리 $(p<0.001)$ 및 희석배 율과 처리간의 상호작용 $(p<0.001)$ 도 유의성이 있는 것으 로 나타났다.

Fig. 3과 Table 1에서 나타난 바와 같이 AAb는 주요장 기들과는 달리 adipocyte PMP에 대해 전 희석배율에서 유 의적으로 $(p<0.05)$ 강한 항원-항체 반응을 나타내었다. 또 한 돼지 $\mathrm{AAb}$ 는 1:3,000배 희석배율에서 피하지방세포에

Table 2. Optical density of antiserum against subcutaneous adipocyte plasma membrane proteins of pigs (SAb) with abdominal and subcutaneous adipocytes, heart, kidney, liver, lung, muscle and spleen of pigs ${ }^{1)}$

\begin{tabular}{lcccc}
\hline \hline \multicolumn{1}{c}{ Items } & $3 \mathrm{k}$ & $9 \mathrm{k}$ & $27 \mathrm{k}$ & $81 \mathrm{k}$ \\
\hline Abdominal adipocyte & $1.810^{\mathrm{a}}$ & $1.428^{\mathrm{b}}$ & $0.882^{\mathrm{b}}$ & $0.505^{\mathrm{b}}$ \\
Subcutaneous adipocyte & $1.913^{\mathrm{a}}$ & $1.743^{\mathrm{a}}$ & $1.382^{\mathrm{a}}$ & $0.744^{\mathrm{a}}$ \\
Heart & $0.633^{\mathrm{b}}$ & $0.559^{\mathrm{cd}}$ & $0.459^{\mathrm{cd}}$ & $0.361^{\mathrm{c}}$ \\
Kidney & $0.690^{\mathrm{b}}$ & $0.564^{\mathrm{cd}}$ & $0.483^{\mathrm{c}}$ & $0.327^{\mathrm{c}}$ \\
Liver & $0.604^{\mathrm{b}}$ & $0.488^{\mathrm{e}}$ & $0.411^{\mathrm{e}}$ & $0.314^{\mathrm{c}}$ \\
Lung & $0.621^{\mathrm{b}}$ & $0.507^{\mathrm{de}}$ & $0.428^{\mathrm{de}}$ & $0.303^{\mathrm{c}}$ \\
Muscle & $0.596^{\mathrm{b}}$ & $0.503^{\mathrm{de}}$ & $0.457^{\mathrm{cd}}$ & $0.330^{\mathrm{c}}$ \\
Spleen & $0.630^{\mathrm{b}}$ & $0.569^{\mathrm{c}}$ & $0.432^{\mathrm{de}}$ & $0.368^{\mathrm{c}}$ \\
SEM & 0.051 & 0.025 & 0.018 & 0.028 \\
\hline
\end{tabular}

a,b,c,d,e Means with different superscripts within the same row are significantly different $(p<0.05)$.

${ }^{1)}$ Optical density was measured at $405 \mathrm{~nm}$ using a microplate reader. Interaction between treatment and dilution rate were significant $(p<0.001)$.

2) Standard error of mean. 
비해 유의적으로 높은 반응을 나타내어 부위별 지방세포 간에도 차이가 있는 것으로 나타났다. 주요장기 (심장, 신 장, 간장, 폐, 근육 및 비장) 세포 원형질막 단백질과 1:3,000 배 희석배율에서 미약한 반응이 나타남을 확인할 수 있으 나, 이는 다클론 항체의 일반적 특성으로 장기와 항체의 직접적인 교차반응이 아니더라도 항체 생산축의 체내 단 백질 등의 비특이적 반응으로도 나타날 수 있는 수준이라 할 수 있다. Fig. 4와 Table 2에 나타난 바와 같이 SAb는 장기세포 단백질들과는 달리 전 희석배율에서 adipocytes $\mathrm{PMP}$ 에 대해 유의적으로 $(p<0.05)$ 강한 반응을 보였다. 개 발된 $\mathrm{AAb}$ 및 $\mathrm{SAb}$ 가 다른 장기의 $\mathrm{PMP}$ 와는 반응이 미약 하거나 거의 없는 반면, 지방세포 PMP와는 특이적으로 높 은 반응을 나타내는 것은 지방세포 PMP에 존재하는 단백 질이 다른 장기 조직과는 차이가 있기 때문일 것으로 판 단되며, 그 지방세포 PMP는 지방세포의 특징인 중성지방 의 축적과 관련이 있는 단백질일 것으로 추측된다(Paik et $a l .$, 2000). 본 연구에서 나타난 부위별 지방세포간 교차반 응은 복강지방세포 원형질막에 존재하는 단백질들의 많은 부분들이 피하지방세포 원형질막에도 존재하기 때문인 것 으로 사료된다(Choi et al., 2008). 1:3,000배의 희석배율에 서 매우 미미하지만 $\mathrm{AAb}$ 및 $\mathrm{SAb}$ 와 장기 세포 $\mathrm{PMP}$ 와의 교차반응이 나타난 것은 다수의 동일한 $\mathrm{PMP}$ 의 존재에서 기인하였다기보다는 항혈청 내 함유된 혈청 단백질들이 ELISA 시 coating된 항원 단백질들과 결합해 발생하는 일 종의 비특이적 반응으로 보는 것이 일반적이다(Baek, 2003). 한편, Paik 등(2000)은 흰쥐 지방세포 항체가 심장의 PMP 와 비교적 높은 교차반응성이 있음을 보고하였고, Nassar 와 $\mathrm{Hu}(1991)$ 는 면양 지방세포 항체 이용 시 비록 지방세 포 PMP와 가장 강한 결합을 보이나, 간장, 심장, 심장, 적 혈구의 순으로 약간의 교차반응이 있음을 보고하였다. 또 한, 흰쥐 지방세포에 대한 다클론 항체는 흰쥐 간세포에 대해 비교적 높은 교차반응성을 나타낸다고 보고되었으며 (Panton et al., 1990), 닭 지방세포에 대한 항체 역시 장기 세포 PMP와 비교적 높은 수준의 교차반응을 나타낸다고 보고되었다(Dong et al., 1991). 그러나, Nassar와 $\mathrm{Hu}(1991)$ 의 연구에서 지방세포 PMP와 다른 장기 PMP가 SDSPAGE상 유사하게 나타났음에도 불구하고, Western blotting 실험 결과 지방세포 PMP와 다른 장기 PMP 간의 양적 및 질적 구성이 서로 달랐음을 보고하였다. Nassar와 $\mathrm{Hu}(1992)$ 는 면양의 지방세포 원형질막에 대해 개발된 다클론 항체 의 교차반응성을 간장, 신장, 심장 및 적혈구의 원형질막 단백질을 이용하여 측정해본 결과, 생산된 항체는 지방세 포에 특이적으로 작용한다고 보고하여 본 연구와 유사한 결과를 나타내었으며, Choi 등(1997)과 Choi 등(2008)도 한우 지방세포 PMP에 대한 항체가 지방세포에 특이적으 로 강한 반응을 나타내는 반면, 간장, 비장, 심장, 신장 등 의 장기 세포 PMP와의 교차반응성은 매우 미약하거나 없

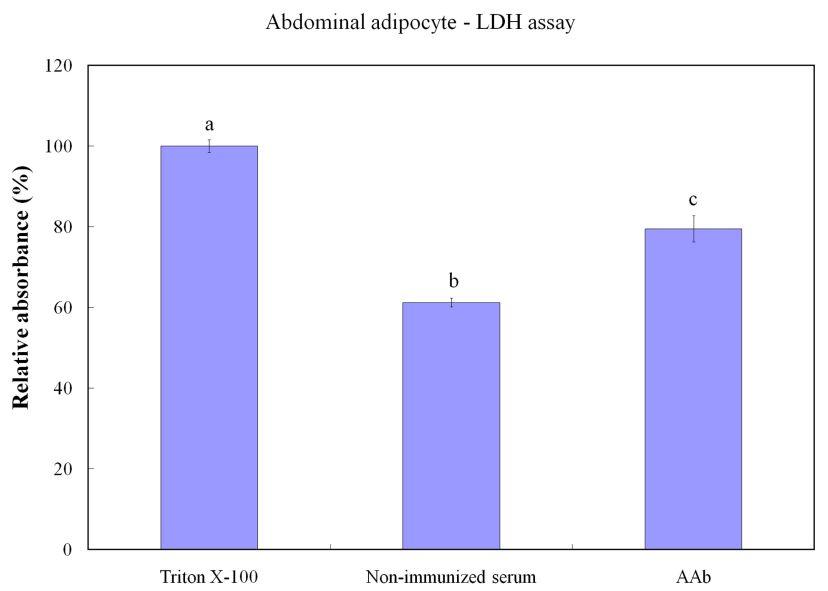

Fig. 5. Relative lactate dehydrogenase (LDH) activity released from confluent abdominal adipocyte culture by antiserum against abdominal adipocyte plasma membrane proteins of pigs (AAb). Mean \pm SE $(n=4)$. Values with different superscripts are significantly different $(p<0.05)$.

는 것으로 보고하였다. 이러한 기존의 연구 결과들을 종 합해볼 때, 본 연구에서 생산한 항체들은 돼지 지방세포에 특이적으로 작용을 하고 있으며, 비록 지방 항체와 주요장 기세포 간의 교차반응 정도는 매우 미약하거나 없다고 판 단된다. 향후 부위별 지방세포 간의 교차반응성을 줄이기 위해서는 부위별 지방 특이 존재 PMP에 대한 선택적 항 체 개발에 대한 추가적인 연구가 필요할 것으로 판단된다.

\section{돼지 부위별 지방세포 특이 항체의 세포독성 효과}

Fig. 5는 돼지 $\mathrm{AAb}$ 가 복강지방세포에게 미치는 in vitro

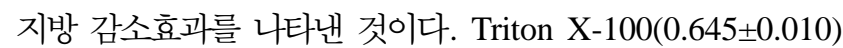
의 지방세포 감소효과를 기준으로 $\mathrm{AAb}(0.513 \pm 0.021)$ 는 비 면역혈청 $(0.395 \pm 0.007)$ 대비 유의적으로 높은 $\mathrm{LDH}$ 수준 을 나타내었다 $(p<0.05)$. 비면역혈청 대비 $\mathrm{AAb}$ 항체처리구 에서 나타난 유의적으로 높은 $\mathrm{LDH}$ 수준은 결국 $\mathrm{AAb}$ 가 살아있는 복강지방 세포에 직접적으로 작용하여 궁극적으 로 지방세포를 용해시켜 배지 내 $\mathrm{LDH}$ 수준을 증가시킨 것으로 보이며, 이는 지방세포에 대한 항체의 세포독성효 과를 간접적으로 보여주고 있는 것이다. 또한 유사하게도 $\mathrm{SAb}(0.594 \pm 0.016)$ 역시 $\mathrm{LDH}$ 수준이 비면역혈청 처리구 $(0.375 \pm 0.032)$ 와 비교해 유의적으로 증가해 $(p<0.05)$, 피하 지방 세포에 강한 세포독성 효과를 나타내고 있음을 확인 할 수 있었다(Fig. 6). Baek 등(2005)은 돼지의 전체 지방 에 대한 항체 처리 시 비면역혈청 대비 유의적인 $(p<0.01)$ 지방세포 감소효과를 보고하였으며, 흰쥐 지방세포에 대 한 항체 처리 시 in vitro 배양중인 지방세포의 $\mathrm{LDH}$ 방출 수준이 증가되었다는 보고와도 유사한 결과이다(Flint et al., 1986; Paik et al., 2000). 최근 한우를 이용해서 실시 한 부위별 지방 항체의 세포독성 연구에서도 각각의 항체 가 in vitro 지방 감소 효과를 나타내고 있고(Choi et al., 


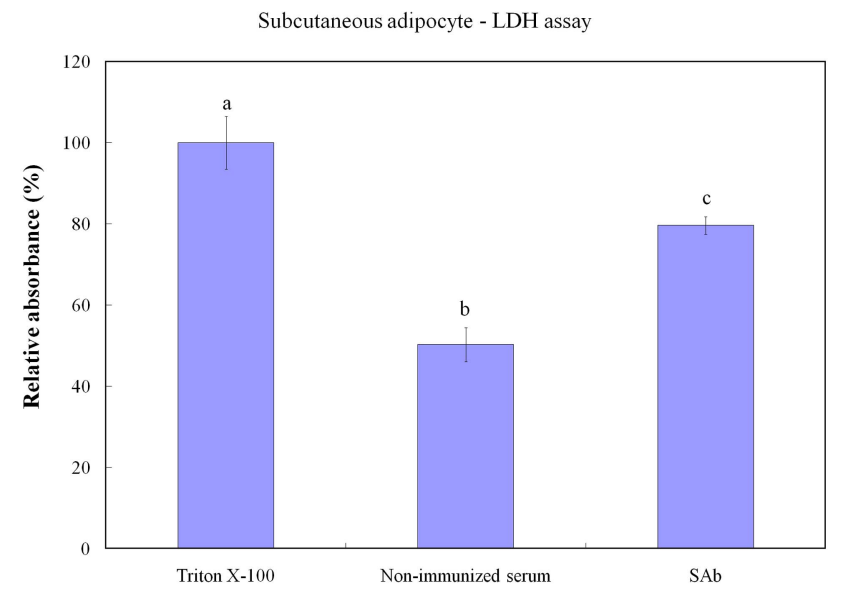

Fig. 6. Relative lactate dehydrogenase (LDH) activity released from confluent subcutaneous adipocyte culture by antiserum against subcutaneous adipocyte plasma membrane proteins of pigs $(\mathrm{SAb}) . M e a n \pm \operatorname{SE}(n=4)$. Values with different superscripts are significantly different $(p<0.05)$.

2008), 특히 닭에서는 지방 항체가 성숙한 지방세포뿐만 아니라 지방전구세포에서도 지방세포 감소효과가 있음이 보고된 바 있다(Butterwith et al., 1989). 이러한 다클론 항 체의 지방세포 독성효과에 대한 메커니즘에 대해서는 현 재까지 명확하게 알려져 있지 않은 실정이지만, 지방 세 포들은 지방의 형태로 생체 에너지를 저장하는 고유 기능 을 가지고 있고(Vernon, 1980), 또한 세포 원형질막의 기능 중 세포내외 간의 신호전달, 영양소 수송, 호르몬 신호의 인지 등이 있음을 볼 때(Lafonton and Berlan, 1984; Slavin, 1987), 현재까지 소개된 항체의 지방 감소 메커니즘에 대 한 여러 이론들 중 항체가 지방대사관련 호르몬 수용체에 결합하여 지방세포에 대한 직접적인 세포독성 효과를 나 타낸다는 이론(Dulor et al., 1990; Kestin et al., 1993; Nassar and $\mathrm{Hu}, 1991)$ 이 가장 유력한 것으로 본 연구팀은 판단하 고 있다. 그 이론을 뒷받침할 과학적 결과로는 전체 지방 에 대한 항체 처리 시 같은 개체에서도 각 부위별 지방 감소량에 차이가 난다는 점(Kestin et al., 1993), 각 축종 별 지방세포 원형질막의 구조가 특이적이며(Cryer et al., 1984), 같은 종이라도 서로 다른 조직 세포의 PMP가 다 르다는 점(Nassar and $\mathrm{Hu}, 1991)$, 그리고 같은 개체의 지 방조직 간에도 서로 다른 $\mathrm{PMP}$ 가 존재한다는 점(Choi et al., 2008) 등을 들 수 있다.

결론적으로 본 연구에서는 면역학적 기법을 이용하여 저 지방 고품질 돈육 생산을 위한 돼지 $\mathrm{AAb}$ 및 $\mathrm{SAb}$ 를 성 공적으로 생산하였으며, 생산된 항체는 살아있는 지방세 포에 대해 매우 강력한 세포독성효과가 있음을 $\mathrm{LDH}$ assay 를 통해 확인할 수 있었다. 따라서 향후, 생산된 항체의 영양생리 및 대사 안전성에 관한 연구, 항체의 생체 지방 감소 효과 및 메카니즘 탐색 연구 등 보다 실증적인 연구
들이 수행될 경우, 불가식 체지방이 감소된 저지방 고품 질 돈육의 생산 또한 가능하리라 사료된다.

\section{요 약}

본 연구는 저지방 고품질 돈육의 생산을 위해 돼지 복 강 및 피하지방 감소를 위한 다클론 항체의 개발 및 실제 세포에 미치는 세포독성효과를 확인하고자 실시되었다. 항 원으로써 돼지의 복강 및 피하지방세포 $\mathrm{PMP}$ 를 분리하여 면양에 3회에 걸쳐 수동면역 주사하고, 면역 주사 전 및 후에 비면역혈청과 항체를 생산하였다. 돼지 $\mathrm{AAb}$ 및 $\mathrm{SAb}$ 항체의 역가와 생체 주요 장기 조직인 심장, 신장, 간장, 폐, 근육 및 비장세포의 $\mathrm{PMP}$ 에 대한 타장기 교차반응성 을 조사하였다. 돼지 부위별 지방 조직에서 지방세포를 분 리하고 각각 primary 배양시킨 후 개발된 $\mathrm{AAb}$ 및 $\mathrm{SAb}$ 를 주입한 뒤 media 내 $\mathrm{LDH}$ 방출 수준을 조사하였다. 희석 배율 $1: 1,000$ 배를 기준으로 비면역혈청은 항원-항체 결합 반응이 거의 측정되지 않았고, $\mathrm{AAb}$ 및 $\mathrm{SAb}$ 는 희석배율 $1: 16,000$ 배까지 각각 항원-항체 반응이 감지되었으며, 이 는 본 연구에서 생산한 부위별 지방 감소 다클론 항체가 지방세포 PMP에 대해 강한 역가를 가진 항체임을 시사한 다. 또한 $\mathrm{AAb}$ 및 $\mathrm{SAb}$ 는 타 장기들과는 특이한 반응을 나 타내지 않았다. 본 연구에서 개발한 두 항체들은 모두 항 원으로 이용된 부위의 지방세포 PMP와 가장 높은 반응을 나타내었으며, 비면역혈청에 비해 유의적으로 높은 세포 독성 효과가 있음을 확인할 수 있었다. 이상의 결과를 종 합할 때 본 연구에서 개발된 $\mathrm{AAb}$ 및 $\mathrm{SAb}$ 는 높은 역가, 타 장기 안전성 및 in vitro 지방 감소 효과가 있었으며 향 후 영양생리 안전성 및 생체 지방 감소 효과 등의 추가 연구가 지속될 경우 저지방 고품질 돈육의 생산이 가능하 리라고 판단된다.

\section{감사의 글}

본 연구는 농촌진흥청 연구사업 수행과제 결과의 일부 로 연구비 지원에 감사 드립니다.

\section{참고문헌}

1. Baek, K. H. (2003) Studies on the production of lean meats and the identification of Hanwoo (Korean Cattle) brand beef using immunological techniques. Ph.D. thesis. Yeungnam Univ., Gyeongsan, Korea.

2. Baek, K. H., Choi, C. W., Choi, C. B., and Lee, B. S. (2007). Passive immunization approach to reduce body fat in pigs using fat-specific polyclonal antiserum. Asian-Aust. J. Anim. Sci. 20, 1594-1599.

3. Baek, K. H., Kwak, T. H., Oh, Y. S., Choi, C. W., Jung, K. K., 
and Choi, C. B. (2005) Studies on the development and utilization of polyclonal antibodies against swine adipocyte plasma membrane proteins. J. Anim. Sci. Technol. (Kor.) 47, 19-28.

4. Butterwith, S. C., Kestin, S., Griffin, H. D., and Flint, D. J. (1989) Cytotoxic antibodies to chicken adipocytes and their precusors: Lack of tissue specificity. Br. Poult. Sci. 30, 371-378.

5. Butterwith, S. C., Kestin, S., Griffin, H. D., Beattie, J., and Flint, D. J. (1992) Identification of chicken (Gallus Domesticus) adipocyte plasma membrane and differentiation specific proteins using SDS-PAGE and western blotting. Comp. Biochem. Physiol. B. 101, 147-151.

6. Choi, C. B., Lee, M. J., and Kwon, E. J. (1997) Development of polyclonal antibody to adipocyte plasma membrane proteins isolated from Korean Naive Cattle. Korean J. Anim. Sci. 39, 669-674.

7. Choi, C. B. and Lee, S. R. (1996) Studies on the production of lean pork by immunological approach - Development of antibodies to porcine adipocyte plasma membrane. Korean $J$. Anim, Sci. 38, 369-374.

8. Choi, C. W., Kim, Y. H., Kim, S. J., Song, M. K., Kwon, E. G., Oh, Y. K., Hong, S. K., Choi, S. H., and Baek, K. H. (2008) Development of polyclonal antibodies to abodominal and subcutaneous adipocytes for fat-reduced Hanwoo beef production. Korean J. Food Sci. Ani. Resour. 28, 651-659.

9. Cryer, A., Gray, B. R., and Woodhead, J. S. (1984) Study on the characterization of bovine adipocytes precursor cells and their differentiation, in vitro, using an indirect-labelled-second antibody cellular immunoassay. J. Develop. Physiol. 6, 159-176.

10. Dong, J., Froman, D. P., and Hu, C. Y. (1991) Development and characterization of polyclonal antibodies against chicken adipocytes. Comp. Biochem. Physiol. A. 99, 195-198.

11. Dulor, J. P., Reyne, Y., and Nougues, J. (1990) In vivo effects of a treatment with antibodies to adipocytes plasma membranes in the rabbit. Reprod. Nutr. Dev. 30, 49-58.

12. Duncan, D. B. (1955) Multiple range and multiple F test. Biometrics. 11, 1-42.

13. Flint, D. J., Coggrave H., C. E. Futter., Gardner, M. J., and Clarke, D. J. (1986) Stimulatory and cytotoxic effects of an antiserum to adipocyte plasma membranes on adipose tissue metabolism in vitro and in vivo. Int. J. Obes. 10, 69-77.

14. Futter, C. E. and D. J. Flint. (1987) Long-term reduction of adiposity in rats after passive immunization with antibodies to rat fat cell plasma membranes. In Recent Advances in Obesity Research. pp. 181-185. [E. M. Berry, editor]. John Libbey.
15. Hu, C. Y., Suryawan, A., Killefer, J., and Wehr, N. B. (1992) Effect of antiserum to rat adipocytes on growth and body composition of the rat. Comp. Biochem. Physiol. 101A. 4, 669-673.

16. Kestin, S., Kennedy, R., Tonner, E., Kiernan, M., Cryer, A., Griffin, H., Butterwith, S., Rhind, S., and Flint, D. J. (1993) Decreased fat content and increased lean in pigs treated with antibodies to adipocyte plasma membranes. J. Anim. Sci. 71, 1486-1494.

17. Lafonton, M. and Berlan, M. (1984) Plasma membrane properties and receptors in while adipose tissue. In New Perspectives in Adipose Tissue: Structure, Function and Development (Edited by Cryer A. and Van R. L. R.) pp. 145-182. Butterworths, London.

18. Moloney, A. P. and Allen, P. (1989a) Immunisation against adipose cells as a possible means of reducing fat deposition in sheep. Ir. J. Agric. Res. 28, 102.

19. Moloney, A. P. and Allen, P. (1989b). Growth and weights of abdominal and carcass fat in sheep immunized against adipose cell membrane. Proc. Nutr. Soc. 48, 14A.

20. Moloney, A. P. (1995) Immunomodulation of fat deposition. Livest. Prod. Sci. 42:239-245.

21. Nassar, A. H. and Hu, C. Y. (1991) Antibodies to ovine adipocyte plasma membranes recognize tissue and species specific plasma membrane components. Comp. Biochem. Physiol. 98B, 361-367.

22. Nassar, A. H. and Hu, C. Y. (1992) Characterization of polyclonal antibodies against ovine adipocyte plasma membranes. Int. J. Biochem. 24, 599-604.

23. Paik, K. H., Kwon, E. J., Kwak, T. H., Jung, K. K., and Choi, C. B. (2000) In vitro cytotoxicity of polyclonal antibodies against proteins isolated from adipocyte plasma membrane of rats. J. Anim. Sci. Technol. (Kor.). 42, 261-268.

24. Panton, D., Futter, C. E., and Kestin, S. (1990) Increased growth and protein deposition in rats treated with antibodies to adipocytes. Am. J. Physiol. 258, E985-E989.

25. SAS (2002) SAS/STAT Software for PC. Release 9.1. SAS Institute. Inc., Cary, NC, USA.

26. Slavin, B. G. (1987) The ultrastructure of adipocytes. In biology of the Adipocyte (Edited by Hausman G. J. and Martin R.), pp. 55-85. Van Nostrand Reinhold, New York.

27. Vernon, R. G. (1980) Lipid metabolism in the adipose tissue of ruminants. Prog. Lipid Res. 19, 23-106.

(Received 2009.7.20/Revised 2010.1.12/Accepted 2010.1.12) 